\title{
Cost of debt and corporate information transparency under economic depression: the case of Greek family-controlled firms
}

\author{
Aikaterini Bethani ${ }^{\mathrm{a}}$, Constantinos G. Chalevas ${ }^{\mathrm{a}, 1}$ \\ and Christos A. Tzovas ${ }^{\mathrm{a}}$ \\ ${ }^{a}$ Athens University of Economics \& Business, Greece
}

\begin{abstract}
Research Question: This study investigates whether corporate information opacity affects the association between family ownership and cost of capital. Motivation: Firms' ownership structure has been identified as a major factor that affects their cost of capital. Idea: Corporate transparency affects the impact of ownership structure upon firms' cost of capital, especially in the case of family-controlled firms Data: We examine a sample of companies listed in the Athens Stock Market for the period of 2009-2016. Tools: We compose a Corporate Opacity Index for each sample firm by adopting the Anderson et al. (2009) approach. Additionally, accounting factors such as firms' size, leverage, profitability and corporate governance characteristics that may affect the above-mentioned association are examined as well. Sensitivity tests have been conducted to check the robustness of the results. Findings: Family ownership and corporate opacity are only marginally related with firms' cost of capital. Firms' size, liquidity and their leverage appear to be inversely associated with their cost of debt capital. Contributions: The findings of this study provide insights regarding the impact that corporate transparency has upon cost of debt capital, allowing financial institutions, regulators and market participants to design improved debt contracts under economic depression. Our study sheds light to the impact of information opacity on the association between family ownership and cost of capital within the business environment of Greece that possesses certain structural characteristics in the context of economic crisis.
\end{abstract}

${ }^{1}$ Corresponding author: Department of Accounting and Finance, Athens University of Economics and Business, Greece; 76, Patission Str. GR-104 34; tel. (+30) 2108203922 ; email addresses: chalevas@aueb.gr 
Keywords: corporate transparency, family-ownership, economic crisis

\author{
JEL codes: G1, G3, M4, O16
}

\title{
1. Introduction
}

The impact of family ownership on the shareholder-debt holder agency cost of debt has been the subject of wide discussion (e.g., Anderson et al., 2003; Boubakri \& Ghouma, 2010; Ellul et al., 2007; Lin et al., 2011; Ma et al., 2015). Previous studies have provided mixed evidence regarding the association between family ownership and firms' cost of debt (Jensen \& Meckling, 1976; Johnson et al., 2000; Anderson et al., 2003; Ellul et al., 2007; Djankov et al., 2008; Fahlenbrach, 2009; Achleitner et al., 2014). This paper investigates the impact that corporate transparency has upon the cost of debt of family-controlled firms. In particular, we focus on corporate information opacity, a factor that is supposed to influence the extent of agency conflicts between firms' managers, equity holders and creditors (Jensen and Meckling, 1976; Smith and Warner, 1979; Bushman and Smith, 2001; Bushman et al., 2004; Sheraz, 2015). The perceived information asymmetry that exists between controlling family shareholders and outside investors may lead to an increase in corporate information opacity and as a consequence an increase in cost of debt (Myers \& Majluf, 1984; La Porta et al., 2000; Ma et al., 2015).

We investigate these issues within the business environment of Greece. The Greek context offers a particular generous environment for such a study. In Greece, as in other European countries (e.g. France, Italy) many listed firms are characterized by a high degree of ownership concentration (Nobes \& Parker, 2000), while a substantial proportion of listed firms can be identified as family controlled (Ballas $\&$ Tzovas, 2010). Bank loans constitute a major source of financing for most Greek firms (Bellas \& Tzovas, 2008). Greece has been classified as a code-law country with low protection of investors and creditors' rights (Chalevas \& Tzovas, 2010; Ballas \& Tzovas, 2010). Furthermore, certain characteristics of Greek culture may prompt Greek firms to prefer confidentiality over transparency (Ballas, 1998; Ballas \& Tzovas, 2010).

Our sample consists of 130 firms listed at the Athens Stock Exchange in the period 2009-2016. We compose a Corporate Opacity Index for each sample firm by adopting the Anderson et al. (2009) approach. We control for sample firms' size, leverage, profitability and corporate governance characteristics. Our findings indicate that family ownership and corporate opacity are only marginally related with firms' cost of capital. The size of borrowing firms appears to be inversely associated with their cost of debt capital. In addition, firms' liquidity and leverage 
reduce cost of debt. Larger companies may benefit from more favorable borrowing terms due to the easier access they may have to capital markets and the long-lasting relations they may have developed with financial institutions.

The findings of this study contribute to the existing literature concerning the impact that ownership structure in general and family ownership in particular, has upon firm's cost of capital. We provide insights regarding the impact that corporate transparency may have upon this cost. The potential significance of the findings of this study is enhanced by the fact that it is conducted within the business environment of Greece that possesses certain structural characteristics. Importantly, this study allows us to examine the above issues under the prism of economic crisis. Greece has experienced a prolonged period of debt crisis that may have influenced the policies of financial institutions and corporations alike. Thus, this study allows us to investigate whether the findings of previous research with relevance to the factors that affect financing cost apply to Greece during the economic crisis. The fact that many European countries have experienced debt crisis, while their business environment possess characteristics similar to the attributes of the business environment of Greece, means that the findings of the present study can be generalized.

The remainder of this paper is organized as follows. Section 2 presents basic characteristics of the Greek business environment. Section 3 discusses the hypotheses regarding the association between family ownership and cost of debt within the context of corporate opacity. Section 4 describes our sample and methodology. In section 5 we discuss the empirical results of our model. In Section 6 we conduct additional tests to check the robustness of our results while Section 7 presents our conclusions.

\section{The Greek business environment}

Traditionally, the ownership structure of most Greek firms is highly concentrated, particularly in the form of family ownership (Tzovas, 2005; Tsalavoutas et al., 2012). In most cases, the owners are actively involved in their firms' management by occupying important posts within firms' organization structure (Sykianakis, 2004; Tzovas, 2006). Managers communicate information directly to their superior owner-managers without having to rely upon publicly disclosed information. Despite the increased role of equity funds, derived mainly through Athens Stock Exchange, banks continue to be one of the main providers of funds of Greek companies. Banks have developed close and long-lasting relationships with companies (Tzovas, 2006). Larger corporations are supposed to enjoy significant political benefits in the form, among others, of easier access to credit capital (Bellas \& Tzovas, 2008). Greece is considered as a code-law country with low 
protection of investors and creditors' rights (Chalevas \& Tzovas, 2010; Ballas \& Tzovas, 2010; Tsalavoutas et al., 2012). In fact, poor legal protection of investors appears to be associated with high ownership concentration (La Porta et al., 1998). Certain aspects of the Greek culture may influence the behavior of Greek firms. Greece is considered to be a low trust society with a strong element of individualism, while large power distances and uncertainty avoidance characterize Greek society (Ballas et al., 1998). The impact of these factors means that Greek firms are more likely to prefer confidentiality over transparency (Ballas \& Tzovas, 2010). Confidentiality may have an impact upon the level of firms' information disclosure (Alexander et al., 2011).

The above mentioned factors are not usually associated with high quality published financial statements (Nobes \& Parker, 2000). In fact, Leuz et al. (2003) show that Greek firms engage in some of the most extreme earnings management practices in the world. Bhattacharya et al. (2003) provide similar evidence, since in their study Greek firms are the most engaged in earnings management among firms from 34 countries. Despite the fact that Greek listed companies have the legal obligation to adopt certain corporate governance mechanisms (Law 3016/2002) and to implement (Law 3229/2004) International Financial Reporting Standards (IFRS hereinafter), more recent evidence suggests that Greek firms continue to manipulate their earnings (Kapoutsou et al., 2015; Papadaki \& Tzovas, 2017).

\section{Literature review and hypotheses development}

The ownership structure of a firm is supposed to be one of its characteristics that is associated with the cost of its debt capital (Anderson et al., 2003). Previous analysis has been inconclusive regarding the impact that family ownership can have upon firms' cost of debt. Due to the dominant position that a controlling family holds in a firm, it is likely to take advantage of its position at the expense of the interests of other shareholders and creditors (Jensen \& Meckling, 1976; Johnson et al., 2000; Ellul et al., 2007; Djakov et al., 2008). In this case there is a direct association between family ownership and firms' cost of debt (Ma et al., 2015). On the other hand, it is maintained that controlling families have an interest in the long-term survival of their firms. As a consequence, family controlled firms are more likely to adopt a long-term and low risk approach (Anderson et al., 2003; Fahlenbrach, 2009; Achleitnere et al., 2014; Muttakin et al, 2014; Ma et al., 2015). Within this context family ownership is expected to reduce firm's cost of debt. Taking into account the above controversial findings we cannot predict in advance the impact that family ownership may have upon firm's cost. Therefore we test the following hypothesis: 


\section{H1. Cost of debt capital is associated with the proportion of family ownership}

The impact that family ownership has upon cost of debt can be conditioned upon a number of factors. Environmental factors such as investor protection can affect the cost of debt for a family firm (Sheraz, 2015). Family firms in countries with high investor protection benefit from lower cost of debt, while in low investor protection countries they may face high debt costs (Ellul et al., 2007). As mentioned earlier Greece is supposed to be a low investor protection country.

A factor that may affect the impact of family ownership on cost of debt is the corporate information opacity perceived to be related with family ownership. The provision of accounting information can reduce the agency costs that may arise between managers, creditors and shareholders (Smith \& Warner, 1979; Watts \& Zimmerman, 1986; Bushman \& Smith, 2001). The use of accounting data in firm's negotiations with the providers of credit capital, and the inclusion of accounting numbers-based terms in the debt agreements indicates that accounting information plays an important role in negotiating debt agreements (Wolfson, 1993; Cloyd et al., 1996; Tzovas, 2001). Transparent corporate information allows creditors to asses firms' credit-worthiness. Besides, accounting information provides the opportunity to borrowing firms and providers of credit capital to design efficient debt covenants that alleviate agency costs between firms and creditors (Armstrong et al., 2010; Ma et al., 2013). Consequently, transparent corporate information reduces credit risk and therefore cost of debt. Conversely, increased corporate information opacity may increase firm's cost of debt as well. Creditors will demand higher return for the investment in order to cover the higher cost of debt contraction (Ma et al., 2015).

The impact that corporate information opacity has upon the cost of debt of family controlled firms is conditioned, among others, upon creditors' perceptions regarding the motives of controlling families. When creditors believe that their interests are aligned with those of controlling family they will be less concerned about the provision of transparent information (Ma et al., 2015). As a consequence, corporate opacity does not significantly affect firms' cost of debt. However, if creditors believe that controlling family is likely to exploit its dominant position at the expense of creditors' interests, they will perceive that corporate information is more opaque and less credible (Leuz et al., 2003). In this case, corporate opacity will increase cost of debt, since creditors will require higher returns for their investment (Armstrong et al., 2010; Ma et al., 2013). Due to the fact that we cannot make a priori prediction about the impact of corporate information opacity upon the association of cost of capital and family ownership, we test the following hypothesis:

H2. Corporate opacity affects the association between cost of capital and family ownership. 


\section{Data and methodology}

\subsection{Sample}

Our sample consists of 1.040 annual observations regarding 130 firms listed in the Athens Stock Exchange for the period 2009 to 2016. Our initial sample consisted of total number of companies listed in Athens Stock Exchange. We excluded all companies from banking, insurance, and real estate sectors. Also, we excluded all companies with missing accounting or governance data and we finally ended up with sample of 130 companies. All public entities domiciled in the European Union were required to prepare group accounts in accordance to IFRS from the 1st January 2005. Thus, all firms in our sample report their financial statements under a uniform accounting framework (IFRS). Table1 presents the companies' distribution across industry sectors. In order to collect quantitative data, Thomson Reuters' DataStream data base was used. Qualitative data was derived from the Athens Stock Market website and the website of Naftemporiki newspaper.

Table 1. Companies' distribution across industry sectors

\begin{tabular}{lr}
\hline Sector & No. of observations \\
\hline Beverages & 1 \\
Chemicals & 4 \\
Construction and Materials & 17 \\
Electricity & 1 \\
Fixed Line Telecommunications & 1 \\
Food Producers & 14 \\
General Industrials & 6 \\
General Retailers & 7 \\
Health Care Equipment and Services & 4 \\
Household Goods and Home Construction & 9 \\
Industrial Engineering & 3 \\
Industrial Metals and Mining & 9 \\
Leisure Goods & 1 \\
Media & 4 \\
Oil and Gas Producers & 2 \\
Personal Goods & 13 \\
Pharmaceuticals and Biotechnology & 1 \\
Software and Computer Services & 10 \\
Total & $\mathbf{1 3 0}$ \\
\hline
\end{tabular}




\subsection{Model specification}

Our research proceeded in two stages. In the first stage, we examined whether family ownership affects firm's cost of debt. In the second stage we investigated whether corporate opacity affects the association between cost of capital and family ownership. In order to test our hypotheses we estimated the following ordinary least square regression model derived from Ma et al. (2015):

COSTOFDEBT $=a+b_{1}$ FAMOWN $+b_{2}$ FAMOWN*OPACITY $+b_{3} O P A C I T Y+$ $b_{4}$ PERSONAL + $b_{5}$ PERSONAL*OPACITY + $b_{6}$ MULTIFOUNDER + $b_{7}$ MULTIFOUNDER*OPACITY $+\Sigma b_{j}$ Control Variable $+\Sigma b_{t}$ Year Dummy + $e(1)$

Where:

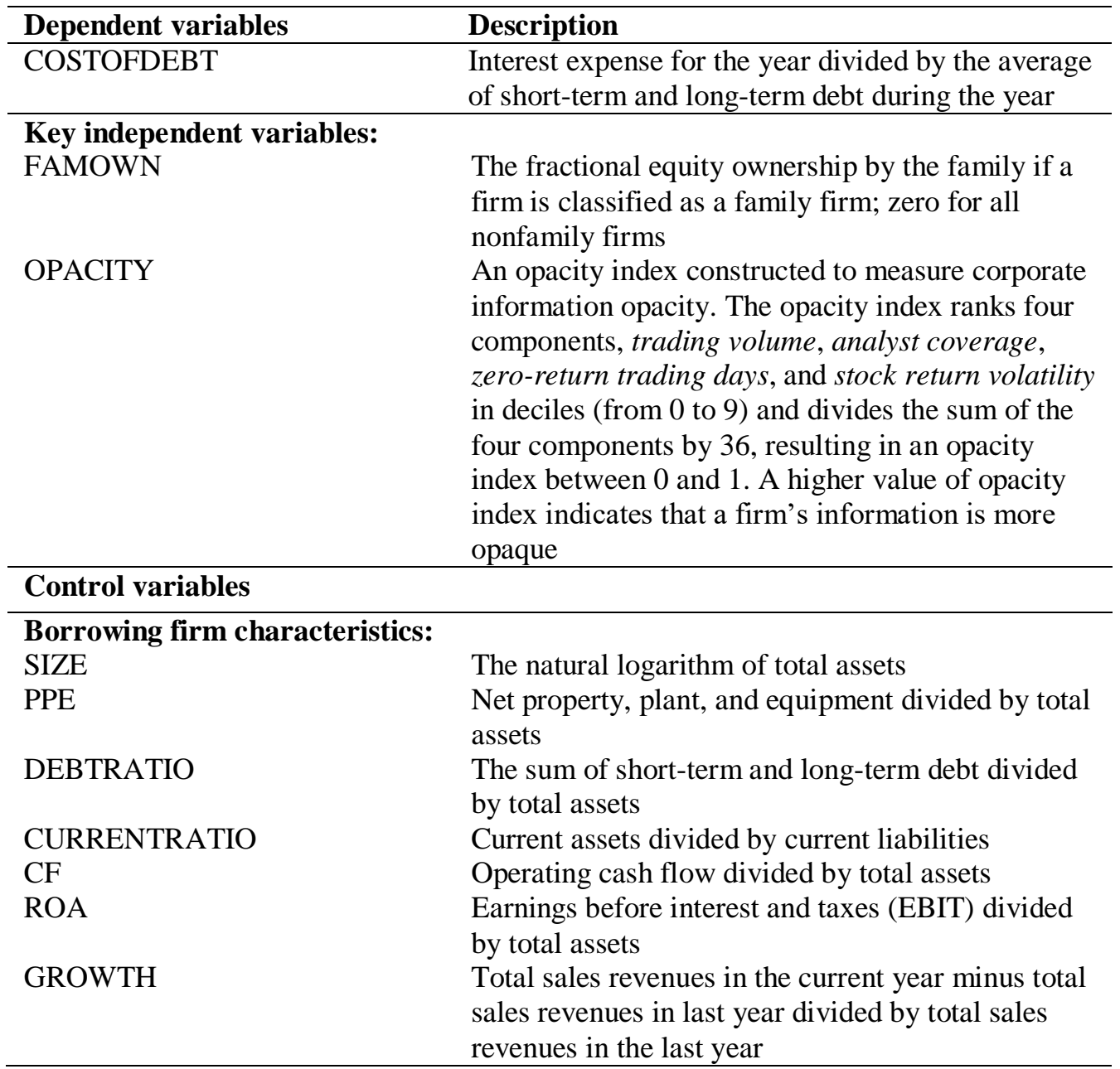

Vol. 18, No. 2 


\begin{tabular}{ll}
\hline Dependent variables & Description \\
\hline NEGEQ & $\begin{array}{l}\text { A dummy variable that equals } 1 \text { if the firm reports } \\
\text { negative equity; zero otherwise } \\
\text { The natural logarithm of the total number of } \\
\text { directors on the board } \\
\text { The number of outside directors divided by total } \\
\text { number of board directors }\end{array}$ \\
OUTDIR & $\begin{array}{l}\text { A dummy variable that equals } 1 \text { if the name of the } \\
\text { firm at the time of IPO contains (part of) personal } \\
\text { name(s) related to the founder(s) }\end{array}$ \\
A dummy variable that equals 1 if the firm has \\
more than one founder
\end{tabular}

In order to investigate whether information opacity affects the impact that family ownership has upon cost of debt we estimated our model for two sample clusters. First cluster consists of low-opacity firms, which are defined as those for which opacity index is below median. The second cluster includes the high-opacity firms, which are defined as those for which opacity-index is above median. If the estimated coefficient for variable $F A M O W N$ is significantly different, it can be inferred that corporate opacity affects the impact that family ownership has upon firm's cost of debt. In the following sections we elaborate upon the main variables of the models.

\subsubsection{Dependent variable}

Following the approach adopted in previous studies (Pittman \& Fortin, 2004; Kim et al., 2011; Sanchez-Ballesta \& Garcia-Meca, 2011; Ma et al., 2015) we measure firm's cost of debt as firm's interest expense for the year divided by the average short-term and long-term debt during the year.

\subsubsection{Independent variables}

\section{Family Ownership}

A number of definitions of family controlled firms have been provide in the literature (see, Prencipe et al., 2014; Ma et al., 2015). As in prior studies (Fan \& Wong, 2002; Dyck \& Zingales, 2004; Tzovas, 2005; Prencipe et al., 2014; Ma et al., 2015) we define a firm as a family controlled on the basis of the percentage of firm's share capital controlled by family members. Most studies classify a firm as family controlled one, when family members own more than $5 \%$ or $10 \%$ of firm's share capital. Given the high concentration of Greek firms' ownership, we adopted a higher threshold in the study. In particular, we use a dummy variable (FAMOWN) to denote a family firm. The dummy variable takes the value 1 (one), when family members directly or indirectly possess a percentage of more than $30 \%$ 
of the company's share capital. Otherwise the dummy variable takes value 0 (zero). In the model we introduce an interaction term between corporate opacity and family ownership, FAMOWN*OPACITY. This term measures the impact that corporate opacity may have upon the association between cost of capital and family ownership. For instance, in case that corporate opacity increases, the inversely association between family ownership and firm's cost of debt becomes weaker. Conversely, the inversely association between family ownership and firm's cost of debt becomes stronger when corporate opacity decreases.

\section{Corporate Opacity}

We compose the corporate opacity index, on the basis of the model proposed by Anderson et al. (2009). The factors included in the index are: zero-return trading days' ratio, daily return volatility, average daily trading volume. Anderson's model includes an additional factor: the number of equity analysts following a firm. We have not included this factor in our index due to the lack of available data. The underlying assumption for this index is that there is a direct association between trading volume and information transparency. That is investors are more willing to participate in transactions when less information asymmetry is present (Ma et al., 2015).

The components of the index were calculated as follows:

- Zero-return trading days over the year. Initially, the daily stock returns were calculated. Subsequently, the number of zero-return trading days was determined. In order to calculate the relative index, the zero-return trading days' number was divided by the sum of trading days of each share in Athens Stock Exchange. Prior research (Lesmond et al., 1999; Bekaert et al., 2007) suggests that rate of zero daily return is a measure of liquidity that captures the value of information signals in relation to the trading costs.

- Stock return volatility. For the calculation of volatility, the standard deviation of daily stock returns (dividend adjusted) during the year was estimated. Lang and Lundholm (1993) argue that stock price volatility is negatively associated with information asymmetry between investors and the firm.

- Trading volume. For the calculation of trading volume we divided the average daily number of shares traded by the average total number of shares outstanding during the year. Leuz and Verrecchia (2000) suggest that trading volume is an inverse proxy for corporate information opacity. 
Subsequently, we construct a corporate opacity index for each firm-year observation of our sample. In order to compose the corporate opacity index, we initially calculate the three individual components of opacity for each firm-year observation of our sample. We then rank each of these three components into deciles, with a value of 0 representing the least opaque firms' value and the value of 9 representing the most opaque firms. The sum of the above three components is divided by a factor of 27 , being the maximum possible value. As a result of this process we have for each firm-year observation a corporate opacity index that ranges from 0 to 1 , with higher values indicating greater information opacity.

\subsubsection{Control variables}

In order to control for other factors that may affect firm's cost of debt we include in our model a set of firm characteristics as control variables. These control variables include: firm's size, the ratio of fixed assets to total assets $(P P E)$, the ratio of debt to total assets (DEBT RATIO), the ratio of current assets to current liabilities (CURRENT RATIO), operating cash flow divided by total assets (CASH FLOW), return on assets $(R O A)$, sales growth $(G R O W T H)$, a dummy variable indicating negative equity (NEGEQ), board size (BOARDSIZE), and the ratio of outside directors to the total number of directors (OUTDIR). Also, we use dummy variables to control for the cases that the name of the founder exists in the name of a family firm (PERSONAL) and also for the firm's ownership state in the context of the founders number (MULTIFOUNDER). The year effect is controlled by dummy variable which takes the value one (1) for each individual year it applies and zero (0) otherwise. Descriptions of the variables are detailed in pages 5 and 6.

\subsubsection{Control for endogeneity}

In order to control for possible endogeneity of our model we include in the model the variables PERSONAL*OPACITY and MULTIFOUNDER*OPACITY (the variables are described in pages 5 and 6). Previous research has shown that a firm is more likely to remain family controlled when the personal name(s) of the founder(s) is included in the name of the firm at the time of the Initial Public Offering (IPO) and when a firm has more than one founder from different families (Adams et al., 2009; Fahlenbrach, 2009). We multiply the above mentioned dummy variables with opacity index (exogenous variable) in order to highlight the impact between family ownership and corporate opacity. 


\section{Results}

\subsection{Descriptive statistics}

Table 2 presents the distribution of family and non-family firms per year. The proportion of family firms increases from $66.15 \%$ in 2009 to $68.46 \%$ in 2016 . It seems that the high level of family ownership is a persistent characteristic of the Greek business environment (Ballas \& Tzovas, 2010).

Table 2. Family and non-family firms distribution

\begin{tabular}{ccccc}
\hline Year & Total & $\begin{array}{c}\text { Family } \\
\text { Companies }\end{array}$ & $\begin{array}{c}\text { Non-family } \\
\text { Companies }\end{array}$ & $\begin{array}{c}\text { Family companies } \\
\text { rate }\end{array}$ \\
\hline $\mathbf{2 0 0 9}$ & 130 & 86 & 44 & $66.15 \%$ \\
$\mathbf{2 0 1 0}$ & 130 & 84 & 46 & $64.61 \%$ \\
$\mathbf{2 0 1 1}$ & 130 & 83 & 47 & $63.84 \%$ \\
$\mathbf{2 0 1 2}$ & 130 & 83 & 47 & $63.84 \%$ \\
$\mathbf{2 0 1 3}$ & 130 & 87 & 43 & $66.92 \%$ \\
$\mathbf{2 0 1 4}$ & 130 & 88 & 42 & $67.69 \%$ \\
$\mathbf{2 0 1 5}$ & 130 & 89 & 41 & $68.46 \%$ \\
$\mathbf{2 0 1 6}$ & 130 & 89 & 41 & $68.46 \%$ \\
\hline
\end{tabular}

Note: The table presents family companies per year. A company is defined as family company when the family ownership rate is more than $30 \%$

Table 3 reports the descriptive statistics, analyzed by family and non-family samples. In order to investigate whether there is a statistically significant difference between the two groups (family versus non-family firms) we apply the MannWhitney-Wilcox test for medians. The corporate opacity index of family firms appear to be significantly higher comparing to the corporate opacity index of the non-family firms, implying that family firm may provide less transparent information. It should be noted that family firms appear to have smaller board of directors and smaller proportion of outside directors. These two characteristics of the board of directors are usually related with lower information transparency (Peasnel et al., 2005; Cornett et al., 2009). These results may suggest that there is information asymmetry between controlling family and other investors that leads to increased information opacity. However, that possible information opacity does not seem to increase cost of debt for family-controlled sample firms. The cost of debt of the family and non-family controlled firms are not significantly different. Thus, principally no evidence in support of Hypothesis 1 is provided.

It is more likely that the name of the founder appears in the name of a family firm, while the non-family firms are more likely to have more than one founder. Family firms appear to be more liquid (CURRENTRATIO) and smaller (SIZE), despite the fact they exhibit a higher ratio of investment in property plant and equipment $(P P E)$. 
Table 3. Descriptive statistics

\begin{tabular}{|c|c|c|c|c|c|c|c|}
\hline & \multicolumn{2}{|c|}{ Total } & \multicolumn{2}{|c|}{ Family Companies } & \multicolumn{2}{|c|}{ Non-family Companies } & \multirow[t]{2}{*}{ T-test } \\
\hline Variables & median & $\begin{array}{l}\text { Standard } \\
\text { deviation }\end{array}$ & median & $\begin{array}{l}\text { Standard } \\
\text { deviation }\end{array}$ & median & $\begin{array}{l}\text { Standard } \\
\text { deviation }\end{array}$ & \\
\hline COSTOFDEBT & 0.1195 & 0.0379 & 0.1196 & 0.3784 & 0.1194 & 0.0382 & $(-0.076)$ \\
\hline OPACITY & 0.4500 & 0.1990 & 0.4889 & 0.1777 & 0.3735 & 0.1904 & $(9.661)^{* * *}$ \\
\hline SIZE & 4.9940 & 0.5603 & 4.8779 & 0.4940 & 5.2224 & 0.6110 & $(9.781)^{* * *}$ \\
\hline PPE & 0.3805 & 0.1846 & 0.3905 & 0.1746 & 0.3608 & 0.2016 & $(-2.453)^{* *}$ \\
\hline DEBTRATIO & 0.3759 & 0.1969 & 0.3770 & 0.2027 & 0.3737 & 0.1852 & $(-0.249)$ \\
\hline $\begin{array}{l}\text { CURRENTRATI } \\
\text { O }\end{array}$ & 1.3588 & 0.6305 & 1.3794 & 0.6500 & 1.3175 & 0.5877 & $(-1.487)$ \\
\hline CF & 0.0338 & 0.0488 & 0.0348 & 0.4860 & 0.0318 & 0.4939 & $(-0.953)$ \\
\hline ROA & 0.0100 & 0.5070 & 0.0098 & 0.0507 & 0.0105 & 0.0491 & $(0.184)$ \\
\hline GROWTH & -0.036 & 0.1520 & -0.033 & 0.1483 & -0.041 & 0.1593 & $(-0.778)$ \\
\hline BOARDSIZE & 0.8661 & 0.1030 & 0.8466 & 0.0969 & 0.9094 & 0.1040 & $(8.837)^{* * *}$ \\
\hline OUTDIR & 0.5702 & 0.1197 & 0.5669 & 0.1154 & 0.5771 & 0.1276 & $(1.336)$ \\
\hline NEGEQ & 0.0846 & 0.2784 & 0.0753 & 0.2689 & 0.0968 & 0.2961 & $(1.013)$ \\
\hline $\begin{array}{l}\text { MULTIFOUND } \\
\text { ER }\end{array}$ & 0.4538 & 0.4981 & 0.3570 & 0.4794 & 0.6438 & 0.4795 & $(9.122)^{* * *}$ \\
\hline PERSONAL & 0.3307 & 0.4707 & 0.4179 & 0.4935 & 0.1595 & 0.3667 & $(-8.662)^{* * *}$ \\
\hline
\end{tabular}

\subsection{Regression results}

Table 4 presents the results of the multivariate analysis regarding the association between family ownership and cost of debt under two different transparency regimes of information (Low - opacity firms and High - opacity firms). The results indicate that $18.8 \%$ of cost of debt variability of low-opacity firms is explained by our model, while the corresponding percentage for high-opacity firms is $25.8 \%$. Further, F-stat is 7.65 for low-opacity firms cluster and 10.67 for high-opacity firms cluster both values significant at 0.01 level.

Family ownership appears to be marginally related to the cost of debt of less opaque companies. In particular, for less opaque firms as family ownership increases the cost of debt of increases as well. These results provide weak support for H1. However, in the case of low opacity companies the variable FAMOWN ${ }^{*} O P A C I T Y$ is negative and marginally significant $($ coef $=-0.067$, $\mathrm{t}$-test $=-$ 1.72). The negative sign of the coefficient implies that as corporate opacity decreases, the direct association between family ownership and cost of debt becomes weaker. These results provide support for $\mathrm{H} 2$ that the impact of family ownership on the cost of debt is affected by corporate opacity at least for the lowopacity firms. 
Cost of debt and corporate information transparency under economic depression: the case of Greek family-controlled firms

Table 4. OLS Regression of Cost of Debt on Family Ownership for Low and High Opacity firms

\begin{tabular}{|c|c|c|c|}
\hline & $\begin{array}{c}\text { Low-opacity } \\
\text { firms }\end{array}$ & & $\begin{array}{l}\text { High-opacity } \\
\text { firms }\end{array}$ \\
\hline FAMOWN & $\begin{array}{l}0.024 * \\
(1.808)\end{array}$ & FAMOWN & $\begin{array}{c}-0.025 \\
(-1.548)\end{array}$ \\
\hline FAMOWN*OPACITY & $\begin{array}{l}-0.067 * \\
(-1.721)\end{array}$ & FAMOWN*OPACITY & $\begin{array}{c}0.044 \\
(1.607)\end{array}$ \\
\hline OPACITY & $\begin{array}{c}0.002 \\
(0.076)\end{array}$ & OPACITY & $\begin{array}{l}-0.028 \\
(-1.030)\end{array}$ \\
\hline SIZE & $\begin{array}{c}-0.014 * * * \\
(-3.898)\end{array}$ & SIZE & $\begin{array}{c}-0.024 * * * \\
(-4.232)\end{array}$ \\
\hline PPE & $\begin{array}{l}-0.019 * \\
(-1.726)\end{array}$ & PPE & $\begin{array}{l}-0.013 \\
(-1.052)\end{array}$ \\
\hline DEBTRATIO & $\begin{array}{c}-0.037 * * * \\
(-3.265)\end{array}$ & DEBTRATIO & $\begin{array}{c}-0.044 * * * \\
(-3.804)\end{array}$ \\
\hline CURRENTRATIO & $\begin{array}{c}-0.011 * * * \\
(-2.846)\end{array}$ & CURRENTRATIO & $\begin{array}{c}-0.017 * * * \\
(-5.167)\end{array}$ \\
\hline $\mathbf{C F}$ & $\begin{array}{c}0.006 \\
(0.139)\end{array}$ & $\mathbf{C F}$ & $\begin{array}{l}0.067 * \\
(1.812)\end{array}$ \\
\hline ROA & $\begin{array}{c}0.001 \\
(0.011)\end{array}$ & ROA & $\begin{array}{l}0.081^{*} \\
(1.962)\end{array}$ \\
\hline GROWTH & $\begin{array}{l}-0.021 * \\
(-1.761)\end{array}$ & GROWTH & $\begin{array}{c}-0.008 \\
(-0.620)\end{array}$ \\
\hline BOARDSIZE & $\begin{array}{c}0.022 \\
(1.093)\end{array}$ & BOARDSIZE & $\begin{array}{c}0.008 \\
(0.397)\end{array}$ \\
\hline OUTDIR & $\begin{array}{c}0.061 * * * \\
(4.300)\end{array}$ & OUTDIR & $\begin{array}{c}-0.017 \\
(-1.241)\end{array}$ \\
\hline NEQEG & $\begin{array}{c}0.001 \\
(0.083)\end{array}$ & NEQEG & $\begin{array}{c}-0.004 \\
(-0.578)\end{array}$ \\
\hline PERSONAL*OPACITY & $\begin{array}{c}0.008 \\
(0.150)\end{array}$ & PERSONAL*OPACITY & $\begin{array}{c}-0.036 \\
(-1.565)\end{array}$ \\
\hline $\begin{array}{l}\text { MULTIFOUNDER * } \\
\text { OPACITY }\end{array}$ & 0.029 & $\begin{array}{l}\text { MULTIFOUNDER * } \\
\text { OPACITY }\end{array}$ & -0.032 \\
\hline PERSONAL & $\begin{array}{c}(0.782) \\
-0.004 \\
(-0.221)\end{array}$ & PERSONAL & $\begin{array}{c}(-1.140) \\
0.017 \\
(1.268)\end{array}$ \\
\hline MULTIFOUNDER & $\begin{array}{c}0.001 \\
(0.109)\end{array}$ & MULTIFOUNDER & $\begin{array}{c}0.010 \\
(0.644)\end{array}$ \\
\hline Constant & $\begin{array}{c}0.164 * * * \\
(5.973)\end{array}$ & Constant & $\begin{array}{l}0.299 * * * \\
(9.896)\end{array}$ \\
\hline $\begin{array}{l}\text { YEAR DUMMIES } \\
\text { Obs }\end{array}$ & $\begin{array}{l}\text { YES } \\
502\end{array}$ & $\begin{array}{l}\text { YEAR DUMMIES } \\
\text { Obs }\end{array}$ & $\begin{array}{l}\text { YES } \\
453\end{array}$ \\
\hline F-statistic & 7.652 & F-statistic & 10.673 \\
\hline Prob (F-statistic) & $0.000 * * *$ & Prob (F-statistic) & $0.000 * * *$ \\
\hline Adjusted R-squared & 0.188 & Adjusted R-squared & 0.258 \\
\hline
\end{tabular}

$\mathrm{t}$-values in parentheses calculated from the heteroscedastic corrected standard errors, (White, 1980).

The variables are defined in Table 1 .

* Significant at the 0.10 level.

** Significant at the 0.05 level.

*** Significant at the 0.01 level.

Vol. 18, No. 2 
A significant negative association exists between firms' size and their cost of debt. This applies for both low-opacity (coef $=-0.014$, $\mathrm{t}$-test=-3.90) and the high-opacity firms (coef $=-0.024$, t-test $=-4.23$ ). Larger firms appear to have easier access to debt financing. Further, it is likely that the providers of debt financing assign greater importance on firm's size as a criterion of credit worthiness, rather than the quality of the information being provided. Similarly, a negative association exists between sample firms' investment in plant and equipment (PPE) and their cost of debt. The association is marginally significant only for low-opacity firms (coef $=-0.009$, t test=-1.73). Current ratio, as an indicator of firm's liquidity, is negatively associated with cost of debt. This association is significant for low-opacity firms $($ coef $=-0.011, \mathrm{t}$-test $=-2.85)$ and high-opacity firms (coef $=-0.017, \mathrm{t}$-test $=-5.17)$ alike. Firms' liquidity may be perceived by creditors as an indicator of firms' ability to repay their debts. The inverse effect that firms' liquidity and value of fixed tangible assets have on firms cost of debt suggest that the providers of debt capital consider these two factors as significant indicators of firms' credit worthiness.

The relation between cost of debt and leverage is negative and statistically significant for the low-opacity firms (coef=-0.037, t-test=-3.27) and for the highopacity firms (coef $=-0.044$, t-test $=-3.80)$ alike. This finding indicates that high borrowing may create long lasting relations between the creditor and the borrowing entity. As a consequence, as the borrowing increases, the cost of debt falls. Pittman and Fortin (2004) argue that, when firms have developed long-lasting relation with banks, confidence between contracting parties increases and thus information asymmetry is reduced. As a consequence cost of debt declines.

The relation between cost of debt and the number of outside members of the board of directors appears with the same sign. The outside directors' role, among others, is to promote corporate transparency, reduce information asymmetry and agency costs. The observed relationship is statistically significant only for the cluster of the low opacity firms (coef $=0.061$, t-test=4.30). It appears that creditors assign importance to the role of outside directors only in the case of low-opacity firms. For low-opacity forms, outside directors seem to reveal information that raises red flags for the creditors.

Collinearity diagnostics were also developed. The coefficients in the correlation matrices (Table 5a, 5b) which fluctuate between -0.7 and 0.7 (Tabachnick \& Fidell, 1996) indicate the lack of multilicolinearity in the calculated models. 


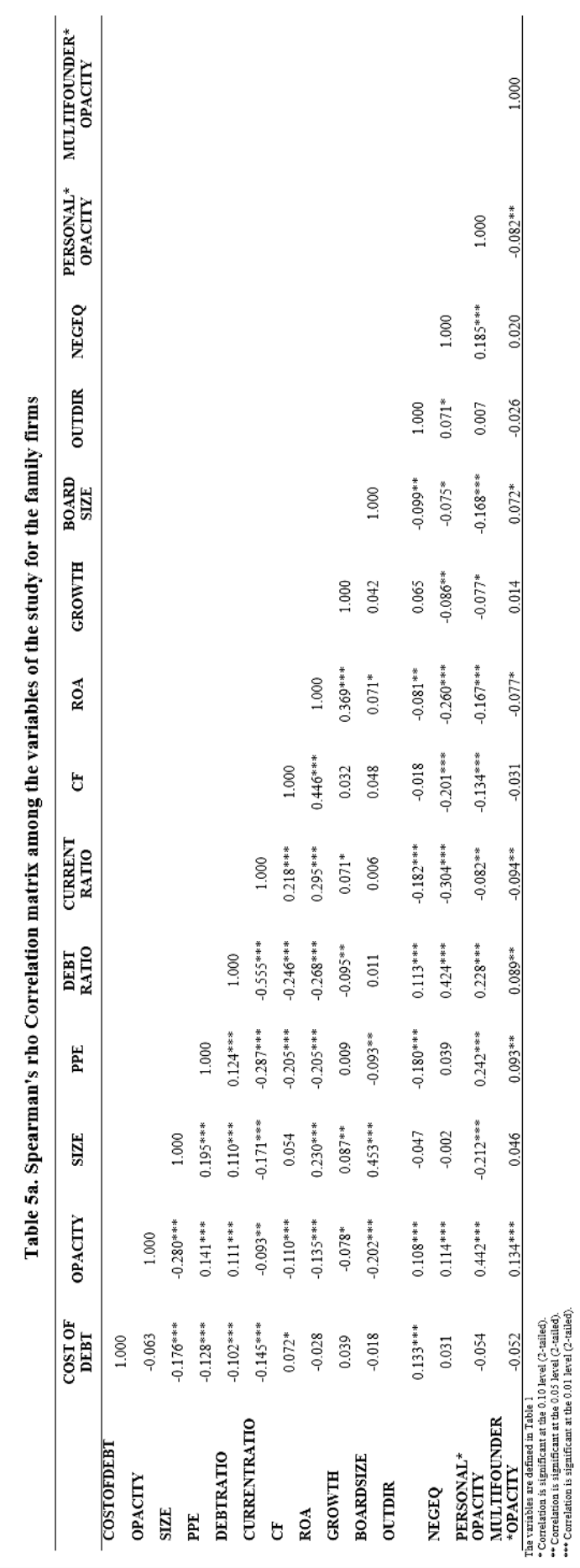

Vol. 18, No. 2 


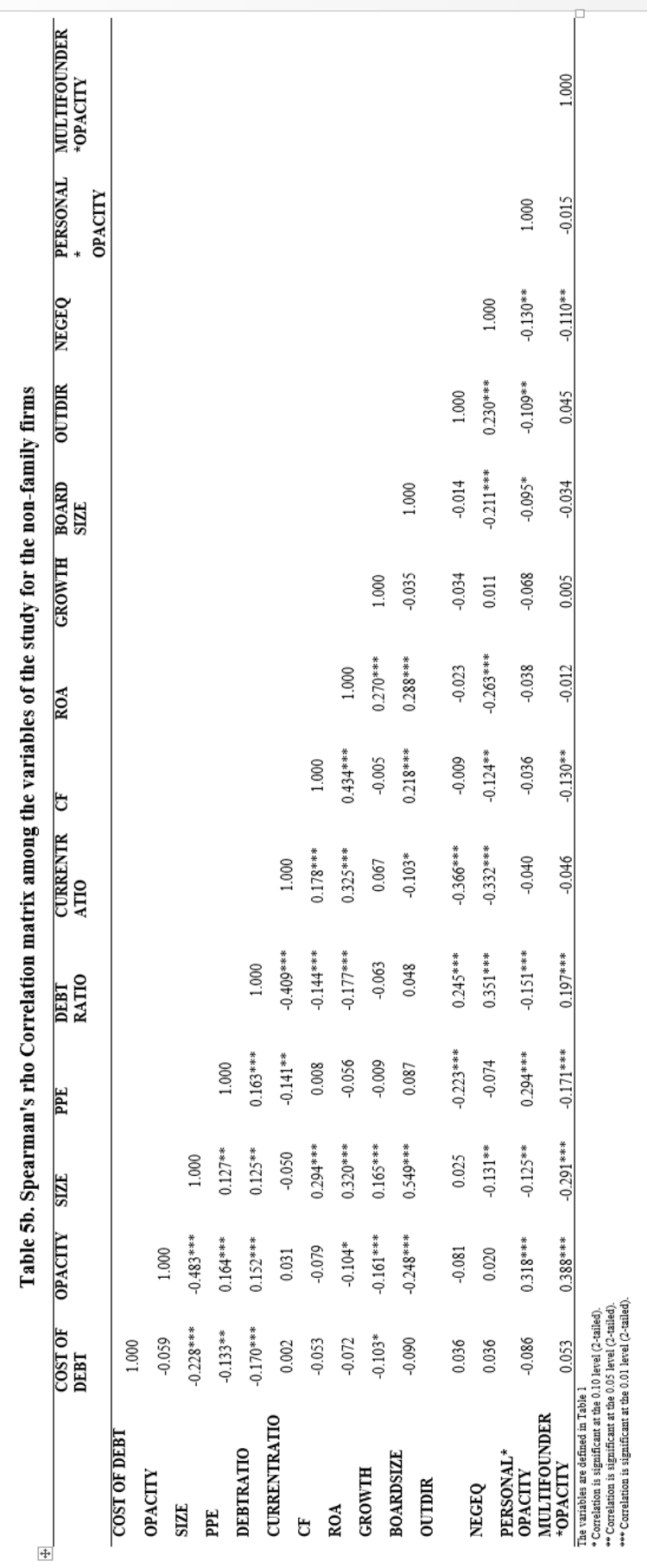




\section{Sensitivity tests}

We examine the joint determination of family ownership and cost of debt, because founding families are more willing to control their firms when they can borrow at low cost. Following Ma et al. (2015) to address for possible endogeneity problem the following simultaneous equation system of family ownership and cost of debt is estimated:

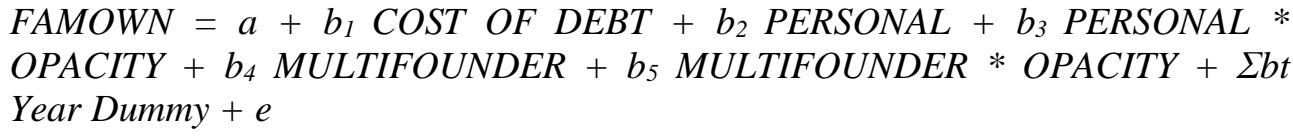

The results presented in Appendix Table 1 do not differ significantly between twostage least squares (2SLS) and OLS analyses.

For the calculation of the corporate opacity index, the Anderson et al. (2009) approach was adopted. Given that the components of our corporate opacity index are solely based on stock-market data, such index may be characterized more as liquidity index, rather than corporate opacity index. In order to check the robustness of our results an alternative corporate opacity index is applied. This index is based on the earnings quality which is negatively correlated with earnings manipulation by firm's management. According to the Greek Law (2190/1920), external certified auditors' reports should provide detailed information regarding:

a) the annual accounts that are the subject to the statutory audit, as well as the specific financial reporting framework applied in their preparation,

b) the scope of statutory audit, including the auditing standards under which the statutory audit was carried out,

c) the matters where auditors wish to draw attention without expressing reservations to the audit opinion.

Auditors not only express but also publish their opinion (audit opinion) clearly on whether the annual accounts give a true and fair view in accordance with the relevant financial reporting framework, whether the annual accounts comply with the law and whether the annual management report of the Management Board corresponds to the annual accounts for the same financial year. 
In this context someone would expect that the audit of the financial statements by one of the Big Four auditors increases the likelihood that the firm's published financial statements provide a fair, complete and accurate representation of its financial position. Therefore it can be considered that transparency and financial reporting integrity depends on auditor's type.

Auditor's type has been used as proxy of earnings quality. Thus, dummy variable (BIGAUDIT) has been used which takes value one (1) if the firm's financial statements are audited by one of the Big Four auditing firms and zero (0) otherwise.

The results for the pool sample are in line with the results presented earlier, enhancing the validity of our findings (Appendix Table 2).

\section{Concluding remarks}

The present study investigates the impact that family ownership has upon Greek firms' cost of capital. We focus on the impact the corporate opacity has upon the association between family ownership and cost of capital. The study period covers the years from 2009 to 2016 in order to shed light to the factors that affect the financing cost under conditions of economic depression. Our results suggest that the cost of debt of Greek firms is only marginally affected by ownership structure. It is likely that family ownership is such a common occurrence in the Greek business environment that is not taken into consideration in the negotiations between lenders and borrowing firms. In fact, the family controlled firms constitute more than $60 \%$ of our sample-firms. In comparison, the percentage of family firms in $\mathrm{Ma}$ et al. (2015) was around 30\%. However, in line with previous research (Armstrong et al., 2010; Ma et al., 2013; Ma et al., 2015), we provide evidence that corporate transparency can be a factor that may affect firms' cost of debt. We found that in the case of low-opacity firms, the direct association between family ownership and cost of debt becomes weaker.

Furthermore, it appears that firms' liquidity and size play important role in determining firms' cost of debt. This can be attributed to the fact that information regarding firms' size and liquidity along with the investment in PPE is easily available information which can be derived with relatively low cost. Furthermore, the structural characteristic of the Greek business environment may affect firms' cost of debt. Larger companies may benefit from more favorable borrowing terms due to the easier access they may have to capital markets and the long-lasting relations they may have developed with financial institutions. The persuasiveness of these characteristics does not appear to be significantly affected by the prolonged debt crisis that has experienced Greek Economy. 


\section{References}

Achleitner, A., Gunther, N., Kaserer, C. \& Siciliano, G. (2014) "Real earnings management and accrual-based earnings management in family firm", European Accounting Review, vol. 23, no.3: 431-461

Adams, R. B., Almeida, H. \& Ferreira, D. (2009) "Understanding the relationship between founder-CEOs and firm performance", Journal of Empirical Finance, vol. 16, no.1: 136-150

Alexander, D., Britton, A. \& Jorissen, A. (2011) International Financial Reporting and Analysis, Melbourne: Thomson Learning

Anderson, R., Duru, A. \& Reeb, D. (2009) "Founders, heirs, and corporate opacity in the United States", Journal of Financial Economics", vol. 92, no 2: 205-222

Anderson, R., Mansi, S. \& Reeb, D. (2003) "Founding family ownership and the agency cost of debt"", Journal of Financial Economics, vol.68, no. 2: 263-285

Armstrong, C. S., Guay, W. R. \& Weber, J. P. (2010) "The role of information and financial reporting in corporate governance and debt contracting", Journal of Accounting and Economics, vol.50, no. 2-3: 179-234

Ballas A. \& Tzovas, C. (2010) "An empirical investigation of Greek firms' compliance to IFRS disclosure requirements", International Journal of Managerial and Financial Accounting, vol. 2, no.1: 40-62

Ballas, A. A., Hevas, D. \& Neil, D. (1998) "The state of accounting and the state of the state", Journal of Management and Governance, vol. 2, no. 2: 267-85

Bekaert, G., Harvey, C. R. \& Lundblad, C. (2007) "Liquidity and expected returns: Lessons from emerging markets", Review of Financial Studies, vol. 20, no. 5: $1783-1831$

Bellas A. \& Tzovas, C. (2008) "the effects of dependency on debt financing on financial reporting policy: the case of Greece", European Research Studies, vol. 11, no. 1-2: 13-31

Bhattacharya, U., Daouk, H. \& Welker, M. (2003) "The world price of earnings opacity", The Accounting Review, vol. 78, no. 3: 641-678

Boubakri, N. \& Ghouma, H. (2010) "Control / ownership structure, creditor rights protection, and the cost of debt financing: International evidence", Journal of Banking and Finance, vol. 34, no. 10: 2481-2499

Bushman, R., Piotroski, J. \& Smith, A. (2004) "What determines corporate transparency?", Journal of Accounting Research, vol. 42, no. 2: 207-252

Bushman, R. M. \& Smith, A. (2001) "Financial accounting information and corporate governance", Journal of Accounting and Economics, vol. 32, no. 1-3: 237-351

Chalevas, C. \& Tzovas, C. (2010) "The effect of Mandatory Adoption of Corporate Governance Mechanisms on Earnings Manipulation, Management 
Effectiveness and Firm Financing: Evidence from Greece", Journal of Managerial Finance, vol. 36, no. 3: 257-277

Cloyd, B.C., Pratt, J. \& Stock, T. (1996) "The use of financial accounting choice to support aggressive tax positions: public and private firms", Journal of Accounting Research, vol. 34, no. 1: 23-43

Cornett, M., McNutt, J. \& Tehranian, H. (2009) "Corporate governance and earnings management at large U.S. bank holding companies", Journal of Corporate Finance, vol. 15, no. 4: 412-430

Djankov, S., La Porta, R., Lopez-de-Silanes, F. \& Shleifer, A. (2008) “The law and economics of self-dealing", Journal of Financial Economics, vol. 88, no. 3: $430-465$

Dyck, A. \& Zingales, L. (2004) "Private benefits of control: An international comparison" ", Journal of Finance, vol. 59, no. 2: 537-600

Ellul, A., Guntay, L. \& Lel, U. (2007) "External governance and debt agency costs of family firms", Federal Reserve International Finance Discussion Paper No. 908

Fahlenbrach, R. (2009) "Founder-CEOs, investment decisions, and stock market performance", Journal of Financial and Quantitative Analysis, vol. 44, no. 2: $439-466$

Fan, J. \& Wong, T. J. (2002) "Corporate ownership structure and the informativeness of accounting earnings in East Asia", Journal of Accounting and Finance, vol. 33, no. 3: 401-425

Jensen, M. \& Meckling, W. (1976) "Theory of the firm: Managerial behavior, agency costs and ownership structure", Journal of Financial Economics, vol. 3, no. 4: 305-360

Johnson, S., La Porta, R., Shleifer, A. \& Lopez-de-Silanes, F. (2000) "Tunneling", American Economic Review Papers and Proceedings, vol. 90, no. 2: 22-27

Kapoutsou, E., Chalevas, C. \& Tzovas, C. (2015) "Earnings management and income tax evidence from Greece", Journal of Corporate Ownership and Control, vol. 12, no. 2: 511-529

Kim, J.B., Simunic, D. A., Stein, M. T. \& Yi, C. H. (2011) "Voluntary audits and the cost of debt capital for privately held firms: Korean evidence", Contemporary Accounting Research, vol. 28, no. 2: 585-615

La Porta, R., Lopez-de-Silanes, F., Shleifer, A. \& Vishny, R. (1998) "Law and finance", Journal of Political Economy, vol. 106, no. 6: 1113-1155

La Porta, R., Lopez-de-Silanes, F., Shleifer, A. \& Vishny, R. (2000) "Investor protection and corporate governance", Journal of Financial Economics, vol. 58, no. 1-2: 3-27

Lang, M. \& Lundholm, R. (1993) "Cross-sectional determinants of analyst ratings of corporate disclosures", Journal of Accounting Research, vol. 31, no. 2: 246-271

Lesmond, D., Ogden, J. \& Trzcinka, C. (1999) "A new estimate of transaction costs”, Review of Financial Studies, Vol. 12 No. 5: 1113-1141 
Leuz, C., Nanda, D. \& Wysocki, P. (2003) "Earnings management and investor protection: an international comparison", Journal of Financial Economics, vol. 69, no. 3: 505-527

Lin, C., Ma, Y., Malatesta, P. \& Xuan, Y. (2011) "Ownership structure and the cost of corporate borrowing", Journal of Financial Economics, vol. 100, no. $1: 1-23$

Ma, L., Ma, S. \& Tian, G. (2013) "Political connection, founder managers, and their impact on tunneling in China's listed firms", Pacific Basin Finance Journal, vol. 24: 312-339

Ma, L., Ma, S. \& Tian, G. (2015) "Corporate opacity and cost of debt for family firms", European Accounting Review, vol. 26, no. 1: 27-59

Muttakin, M. B., Khan, A. \& Subramaniam N. (2014) "Family firms, family generation and performance: evidence from an emerging economy", Journal of Accounting in Emerging Economies, vol. 4, no. 2: 197-219

Myers, S. C. \& Majluf, N. S. (1984) "Corporate financing and investment decisions when firms have information that investors do not have", Journal of Financial Economics, vol. 13, no. 2: 187-221

Nobes, C. \& Parker, R. (2000) Comparative International Accounting, $6^{\text {th }}$ Edition, Financial Times-Prentice Hall

Papadaki, A. \& Tzovas, C. (2017) "Financial crisis and accrual and real earnings management in Europe", Journal of Corporate Ownership and Control, vol.14, no. 3: 8-19

Peasnell, K. V., Pope, P. F. \& Young, S. (2005) "Board monitoring and earnings management: do outside directors influence abnormal accruals?", Journal of Business Finance and Accounting, vol. 32, no. 7-8: 1311-1346

Pittman, J. A. \& Fortin, S. (2004) "Auditor choice and the cost of debt capital for newly public firms", Journal of Accounting and Economics, vol. 37, no. 1: 113-136

Prencipe, A., Bar-Yosef, S. \& Dekker, H. C. (2014) "Accounting research in family firms: Theoretical and empirical challenges", European Accounting Review, vol. 23, no. 3: 361-385

Sanchez-Ballesta, J. P. \& Garcia-Meca, E. (2011) "Ownership structure and the cost of debt", European Accounting Review, vol. 20, no. 2: 389-416

Sheraz A., (2015) "Determinants of the quality of disclosed earnings and value relevance across transitional Europe", Journal of Accounting in Emerging Economies, vol. 5, no.3: 325-349

Smith, C. W. \& Warner, J. (1979) "On financial contracting: An analysis of bond covenants", Journal of Financial Economics, vol. 7, no. 2: 117-161

Sykianakis, N. (2004) "Factors affecting Greek FDI in the Balkans: the case of icecream industry", Archives of Economic History, vol. 15, no. 2: 85-107

Tabachnick, B. G. \& Fidell, L. S. (1996) Using Multivariate Statistics (3rd ed.), New York Harper Collins

Tzovas, C. (2005) "The Depreciation Policy Decisions of Industrial Firms: Tax Benefits versus Non-Tax Costs", Spoudai, vol. 55, no.2: 48-77 
Tzovas, C. (2006) "Factors Influencing Firms' Accounting Policy Decisions When Tax Accounting and Financial Accounting Coincide", Managerial Auditing Journal, vol. 21, no. 4: 372-386

Tzovas, C. (2001) "The economic determinants of reporting policies of Greek firms: the influence of tax considerations", Archives of Economic History, vol. 13 , no. 1:7-26

Tsalavoutas, I., Audre, P. \& Evans, L. (2012) "The transition to IFRS and the value relevance of financial statements in Greece", The British Accounting Review, vol. 44, no. 4: 262-277

Watts, R. L. \& Zimmerman, J. L. (1986) Positive accounting theory, Prentice-Hall, Englewood Cliffs, NJ

Wolfson, M. (1993) "The effects of ownership and control on tax and financial reporting policy", Economic Notes, vol. 22, no. 2: 318-332 


\section{APPENDIX}

Table 1. 2SLS regression results of the simultaneous equation Model 2 on

Cost of Debt and Family Ownership for Low and High Opacity Firms 2SLS Model

\begin{tabular}{lcc}
\hline & Panel A & \\
\hline FAMOWN (Dependentvariable) & Low-opacity firms & High-opacity firms \\
COSTOF DEBT & 0.404 & -0.167 \\
PERSONAL & $(0.776)$ & $(-0.289)$ \\
& -0.043 & 0.010 \\
PERSONAL*OPACITY & $-0.340)$ & $(0.087)$ \\
& $0.842^{* *}$ & 0.196 \\
MULTIFOUNDER & $(2.398)$ & $(1.084)$ \\
MULTIFOUNDER*OPACITY & $-0.590^{* * * *}$ & $0.268^{* *}$ \\
& $(-7.016)$ & $(2.112)$ \\
Constant & $0.865^{* * *}$ & $-0.569^{* * *}$ \\
& $(3.592)$ & $(-2.760)$ \\
YEAR DUMMIES & $0.635^{* * *}$ & $0.775^{* * *}$ \\
& $(7.374)$ & $(7.947)$ \\
Obs & YES & YES \\
chi2 & & \\
Prob & 502 & 453 \\
Adjusted R-squared & & \\
& 120.49 & 24.66 \\
\hline
\end{tabular}


Table 1 (continued)

Panel B

COSTOFDEBT (Dependent variable)

Low-opacity firms High-opacity firms

FAMOWN

$\begin{array}{cc}0.017 & -0.049 \\ (0.941) & (-1.471) \\ -0.021 & 0.078 \\ (-0.324) & (1.409) \\ 0.012 & -0.068^{*} \\ (0.363) & (-1.958)\end{array}$

SIZE

$-0.012 * * *$

$-0.016 * * *$

FAMOWN*OPACITY

$(-3.749)$

$(-4.255)$

PPE

$-0.028 * * *$

$-0.019 * *$

DEBTRATIO

$(-3.140)$

$(-2.291)$

$-0.022 * * *$

$-0.045 * * *$

CURRENTRATIO

$(-2.716)$

$(-5.178)$

$-0.010 * * *$

$-0.012 * * *$

CF

$(-4.882)$

$(-6.029)$

0.018

$0.057 * * *$

(0.614)

(2.836)

ROA

0.021

$0.043 * *$

(0.924)

(1.970)

GROWTH

0.000

$-0.001$

$(-1.057)$

$(-0.169)$

BOARDSIZE

0.017

0.002

(0.796)

(0.085)

OUTDIR

$0.039 * * *$

$-0.028 * *$

NEGEQ

$(-2.703)$

$(-2.120)$

0.000

$-0.005$

(0.045)

$(-0.728)$

Constant

$0.174 * * *$

$0.302 * * *$

YEAR DUMMIES

$\begin{array}{cc}(7.874) & (8.751) \\ \text { YES } & \text { YES }\end{array}$

Obs

502

453

chi2

134.89

189.75

Prob

(0.000)

(0.000)

0.212

0.295

Adjusted R-squared

$\mathrm{t}$-values in parentheses calculated from the heteroscedastic corrected standard errors, (White, 1980).

The variables are defined in Table 1 .

* Significant at the 0.10 level.

** Significant at the 0.05 level.

*** Significant at the 0.01 level. 
Cost of debt and corporate information transparency under economic depression: the case of Greek family-controlled firms

Table 2. OLS Regression of Cost of Debt on Family Ownership Dependent variable: COSTOFDEBT

FAMOWN $-0.010^{*}$

$(-1.806)$

FAMOWN*BIGAUDIT

0.009

$(-1.347)$

BIGAUDIT

$-0.004$

$(-0.579)$

SIZE

$-0.014 * * *$

PPE

$(-5.187)$

$-0.022 * * *$

DEBTRATIO

$(-3.114)$

$-0.039 * * *$

$(-4.689)$

CURRENTRATIO

$-0.013 * * *$

$(-5.519)$

0.042

CF

$(-1.483)$

ROA

0.027

(0.859)

GROWTH

$-0.016^{*}$

(-1.696)

0.016

BOARDSIZE

$(-1.211)$

OUTDIR

0.017

$(-1.610)$

NEGEQ

0.001

(0.285)

$-0.010$

$(-1.427)$

0.005

MULTIFOUNDER*BIGAUDIT

(0.816)

PERSONAL

0.006

(0.992)

MULTIFOUNDER

$-0.003$

$(-0.544)$

Constant

$0.211 * * *$

(-11.009)

YES

YEAR DUMMIES

954

Obs

F-statistic

Prob (F-statistic)

0.175

Adjusted R-squared

$\mathrm{t}$-values in parentheses calculated from the heteroscedastic corrected standard errors, (White, 1980).

The variables are defined in Table 1.

* Significant at the 0.10 level.

** Significant at the 0.05 level.

*** Significant at the 0.01 level. 